\title{
Front Matter: Volume 7614
}

, "Front Matter: Volume 7614," Proc. SPIE 7614, Laser Refrigeration of Solids III, 761401 (13 March 2010); doi: 10.1117/12.855146

SPIE. Event: SPIE OPTO, 2010, San Francisco, California, United States 


\section{PROCEEDINGS OF SPIE}

\section{Laser Refrigeration of Solids III}

Richard I. Epstein

Mansoor Sheik-Bahae

Editors

28 January 2010

San Francisco, California, United States

Sponsored and Published by

SPIE

Volume 7614

Proceedings of SPIE, 0277-786X, v. 7614 
The papers included in this volume were part of the technical conference cited on the cover and title page. Papers were selected and subject to review by the editors and conference program committee. Some conference presentations may not be available for publication. The papers published in these proceedings reflect the work and thoughts of the authors and are published herein as submitted. The publisher is not responsible for the validity of the information or for any outcomes resulting from reliance thereon.

Please use the following format to cite material from this book:

Author(s), "Title of Paper," in Laser Refrigeration of Solids III, edited by Richard I. Epstein, Mansoor Sheik-Bahae, Proceedings of SPIE Vol. 7614 (SPIE, Bellingham, WA, 2010) Article CID Number.

ISSN 0277-786X

ISBN 9780819480101

Published by

SPIE

P.O. Box 10, Bellingham, Washington 98227-0010 USA

Telephone +1 3606763290 (Pacific Time) · Fax +1 3606471445

SPIE.org

Copyright (C) 2010, Society of Photo-Optical Instrumentation Engineers

Copying of material in this book for internal or personal use, or for the internal or personal use of specific clients, beyond the fair use provisions granted by the U.S. Copyright Law is authorized by SPIE subject to payment of copying fees. The Transactional Reporting Service base fee for this volume is $\$ 18.00$ per article (or portion thereof), which should be paid directly to the Copyright Clearance Center (CCC), 222 Rosewood Drive, Danvers, MA 01923. Payment may also be made electronically through CCC Online at copyright.com. Other copying for republication, resale, advertising or promotion, or any form of systematic or multiple reproduction of any material in this book is prohibited except with permission in writing from the publisher. The CCC fee code is 0277-786X/10/\$18.00.

Printed in the United States of America.

Publication of record for individual papers is online in the SPIE Digital Library.

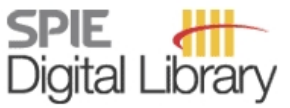

SPIEDigitalLibrary.org

Paper Numbering: Proceedings of SPIE follow an e-First publication model, with papers published first online and then in print and on CD-ROM. Papers are published as they are submitted and meet publication criteria. A unique, consistent, permanent citation identifier (CID) number is assigned to each article at the time of the first publication. Utilization of CIDs allows articles to be fully citable as soon they are published online, and connects the same identifier to all online, print, and electronic versions of the publication. SPIE uses a six-digit CID article numbering system in which:

- The first four digits correspond to the SPIE volume number.

- The last two digits indicate publication order within the volume using a Base 36 numbering system employing both numerals and letters. These two-number sets start with 00, 01, 02, 03, 04, $05,06,07,08,09,0 A, 0 B \ldots 0 Z$, followed by 10-1Z, 20-2Z, etc.

The CID number appears on each page of the manuscript. The complete citation is used on the first page, and an abbreviated version on subsequent pages. Numbers in the index correspond to the last two digits of the six-digit CID number. 


\section{Contents}

$\checkmark$ Conference Committee

\section{SESSION 1 SOLID-STATE LASER COOLING I}

761403 Optical refrigeration breaks the Peltier barrier: cooling Yb:YLF to 155K (Invited Paper) [7614-02]

D. V. Seletskiy, S. D. Melgaard, M. Sheik-Bahae, The Univ. of New Mexico (United States);

S. Bigotta, A. DiLieto, M. Tonelli, NEST-CNR-INFM, Univ. di Pisa (Italy); R. I. Epstein, Los Alamos National Lab. (United States)

761404 Crystal-field effects in fluoride crystals for optical refrigeration (Invited Paper) [7614-03] M. P. Hehlen, Los Alamos National Lab. (United States)

\section{SESSION 2 SOLID-STATE LASER COOLING II}

761406 High-power fiber lasers with integrated rare-earth optical cooler [7614-05]

G. Nemova, R. Kashyap, Ecole Polytechnique de Montréal (Canada)

761407 Spectroscopy of Yb-doped YLF crystals for laser cooling [7614-06]

S. Melgaard, D. Seletskiy, M. Sheik-Bahae, The Univ. of New Mexico (United States);

S. Bigotta, A. DiLieto, M. Tonelli, Univ. di Pisa (Italy); R. Epstein, Los Alamos National Lab. (United States)

\section{SESSION 3 SOLID-STATE LASER COOLING III}

761409 Laser cooling of a semiconductor load using a Yb:YLF optical refrigerator [7614-08]

D. V. Seletskiy, S. Melgaard, M. Sheik-Bahae, The Univ. of New Mexico (United States);

S. Bigotta, A. DiLieto, M. Tonelli, NEST-CNR-INFM, Univ. di Pisa (Italy)

$76140 \mathrm{~A}$ Local internal and bulk optical cooling in Nd-doped crystals and nanocrystalline powders (Invited Paper) [7614-09]

A. J. Garcia-Adeva, Escuela Técnica Superior de Ingeniería (Spain); R. Balda, Escuela Técnica Superior de Ingeniería (Spain) and Ctr. de Física de Materiales CSIC-UPV/EHU and Donostia International Physics Ctr. (Spain); M. Al Saleh, Escuela Técnica Superior de Ingeniería (Spain); J. Fernandez, Escuela Técnica Superior de Ingeniería (Spain) and Ctr. de Física de Materiales CSIC-UPV/EHU and Donostia International Physics Ctr. (Spain)

$7614 \mathrm{OB}$ Characterization of external quantum efficiency and absorption efficiency in GaAs/InGaP double heterostructures for laser cooling applications [7614-10]

C. Wang, M. P. Hasselbeck, C.-Y. Li, M. Sheik-Bahae, The Univ. of New Mexico (United States) 
7614 OD Theory of time-resolved photo-luminescence and carrier lifetime measurements in GaAs/GalnP heterostructures (Invited Paper) [7614-12]

G. Rupper, N. H. Kwong, R. Binder, College of Optical Sciences, The Univ. of Arizona (United States)

7614 OE Determination of nonradiative recombination in high quantum efficiency GaAs/InGaP heterostructures [7614-13]

C.-Y. Li, C. Wang, M. P. Hasselbeck, M. Sheik-Bahae, K. J. Malloy, The Univ. of New Mexico (United States)

7614 OF Thermophotonic heat pump: towards the first demonstration of electroluminescent cooling? [7614-15]

J. Oksanen, J. Tulkki, Helsinki Univ. of Technology (Finland)

Author Index 


\title{
Conference Committee
}

\author{
Symposium Chair
}

E. Fred Schubert, Rensselaer Polytechnic Institute (United States)

Symposium Cochairs

Liang-Chy Chien, Kent State University (United States)

James G. Grote, Air Force Research Laboratory (United States)

Program Track Chair

Zameer U. Hasan, Temple University (United States)

Conference Chairs

Richard I. Epstein, Los Alamos National Laboratory (United States)

Mansoor Sheik-Bahae, The University of New Mexico (United States)

Program Committee

Rolf H. Binder, College of Optical Sciences, The University of Arizona (United States)

Zameer U. Hasan, Temple University (United States)

Jacob B. Khurgin, The Johns Hopkins University (United States)

Yong-Hang Zhang, Arizona State University (United States)

\section{Session Chairs}

1 Solid-State Laser Cooling I

Kent L. Miller, Air Force Office of Scientific Research (United States)

2 Solid-State Laser Cooling II

Joaquín Fernández, Universidad del País Vasco (Spain)

3 Solid-State Laser Cooling III

Markus P. Hehlen, Los Alamos National Laboratory (United States)

4 Solid-State Laser Cooling IV

Denis Seletskiy, The University of New Mexico (United States) 
Downloaded From: https://www.spiedigitallibrary.org/conference-proceedings-of-spie on 26 Apr 2023

Terms of Use: https://www.spiedigitallibrary.org/terms-of-use 